\title{
Role modeling in clinical educators: An important issue in medical education
}

\author{
Rabeya Yousuf', Abdus Salam ${ }^{2}$ \\ ${ }^{1}$ Blood Bank Unit, Department of Pathology, ${ }^{2}$ Department of Medical Education, Faculty of Medicine, Universiti Kebangsaan \\ Malaysia (UKM) Medical Centre, Malaysia
}

The importance of positive role modeling by clinical educators is recognized worldwide to help professional development of learners. Students evaluate role models in clinical educators according to teaching qualities (related to knowledge - 'Head'), personal qualities (related to attitude - 'Heart'), and patient care qualities (related to activities - 'Hands on')., ${ }^{1,2}$ So role modeling in clinical educators involves the integration of the " $3 \mathrm{Hs}$ " as a unity all the time and everywhere by the clinical trainers.

The teaching qualities in a positive role model include a humanistic style of teaching with the establishment of a rapport with learners, and to be accessible to trainees for any questions or make him or her available for trainees, and accessible for questions. ${ }^{3}$ They spent more time on teaching and conducting rounds and were more likely to stress the importance of the doctor-patient relationship and psychosocial aspects of medicine. The personality profile of a positive role model shows they are cooperative, honest, patient, has self-esteem and selfconfidence. ${ }^{3}$ The patient care qualities include the clinical competence, experienced clinicians with a commitment to excellence and growth, effective in diagnostic and therapeutic skills with sound clinical reasoning and a good communication skill with the patients as well as others. ${ }^{3,4}$ Good humanistic behavior is an important issue for a good role model which includes their caring attitude, empathy and respect for the patients. ${ }^{5}$

Role models help new medical graduates to develop a high standard of professionalism as well as influence their career choices and satisfaction with their training. ${ }^{6}$ This learning takes place unconsciously and can transmit both positive and negative effects on the students. Students learn by directly observing the behaviors of their teachers and imitating the behaviors in their own life. Thus role models function not only at the bedside or clinic, but virtually in any situation where a student can observe a clinical teacher. ${ }^{7}$ Good role models impart a great job in the informal curriculum of medical professionalism by which professional values, attitudes, and behaviors have been handed down from generation to generation. ${ }^{8}$

A major challenge for clinical educators is to become a role model while delivering high standards of professionalism during their clinical teaching. ${ }^{6}$ It has been found that more than $50 \%$ of the faculty were not perceived as positive role models by the residents; rather they were seen as negative role models. ${ }^{6}$ Students often receive conflicting messages between what they learn in the classroom and what they observe in client settings. ${ }^{9}$ Persistence of hierarchy and exclusivity by senior doctors has been described by the students as negative role modeling that adversely affects the professional behavior and career choices of trainees. ${ }^{10}$

Students are the direct observer of the positive and negative behavior of the educators. Clinical teachers can enhance their performance as role models by being more consciously aware of their role as a role model. They have to consciously realize that all of their interactions, personal opinions, and attitudes are followed and observed by the students in any situation. ${ }^{11}$ Thus, clinical educators with good clinical skills and holistic doctor-patient relationships in general practice can encourage the students in the learning of these skills. So conscious and selfawareness among the educators in all the aspects of teaching, personal qualities and patient care are the back bone for good role modeling. It is of utmost importance for the educators to be a good role model and to display exemplary behavior in both within and outside the classroom, as the learning of future medical graduates depends mostly on them.

Regular faculty development training targeted for clinical educators can help to develop role modeling awareness and competencies. ${ }^{12}$ To raise awareness about teaching responsibilities among clinical faculty members, some of the strategies suggested by Mileder ${ }^{11}$ include: implementation of development programs on active teaching, delivering feedback, professional behavior, and ethics both in undergraduate and graduate curricula, training of clinical teachers in selfreflective practice, provision of institutional support in terms of both administrative and financial, allocation of sufficient teaching time and focus on small-group teaching, formal institutional recognition of dedicated clinical teachers, standardization of teaching contents and communication of clinical learning objectives and thorough assessment of organizational 'framework' and of explicit as well as implicit teaching and learning.

Medical schools should pay attention by doing selfevaluation and regular faculty development training to enhance the motivation and efficiency of the clinical educators and thereby help them to understand the complex phenomenon of role modeling. ${ }^{10}$

Correspondence: Assoc. Prof. Dr. Abdus Salam, Medical Education Department, Faculty of Medicine, UKM Medical Centre. Jalan Yaakob Latif, Bandar Tun Razak, Cheras, 56000 Kuala Lumpur, Malaysia. E-mail: abdussalam.dr@gmail.com.

South East Asia Journal of Public Health 2015;5(1):49-50. (C) 2015 Yousuf \& Salam, publisher and licensee Public Health Foundation Bangladesh. This is an Open Access article which permits unrestricted non-commercial use, provided the original work is properly cited. DOI: http://dx.doi.org/10.3329/seajph.v5i1.24853 


\section{References}

1. Wright S. Examining what residents look for in their role models. Acad Med 1996; 71:290-2.

2. Jochemsen-van der Leeuw HGAR, van Dijk N, Wieringa-de Waard $M$, Assessment of the Clinical Trainer as a Role Model: A Role Model Apperception Tool (RoMAT). Acad Med 2014; 89:671-7.

3. Jochemsen-van der Leeuw HGAR, van Dijk N, van Etten-Jamaludin FS, Wieringa-de Waard M. The Attributes of the Clinical Trainer as a Role Model: A Systematic Review. Acad Med 2013; 88(1): 26-34.

4. Cruess SR, Cruess RL, Steinert Y. Role modeling-Making the most of a powerful teaching strategy. BMJ 2008; 336:718-21.

5. Burgess A, Goulston K, Oates K. Role modelling of clinical tutors: a focus group study among medical students. BMC Med Edu 2015; 15:17.

6. Lombarts KMJMH, Heineman MJ, Arah OA. Good Clinical Teachers Likely to be Specialist Role Models: Results from a Multicenter CrossSectional Survey. PLoS ONE 2010; 5(12): e15202. 0015202.
7. Althouse LA, Stritter FT, Steiner BD. Attitudes and approaches of influential role models in clinical education. Adv Health Sci Educ Theory Pract 1999;4:111-22.

8. Paice E, Heard S, Moss F. How important are role models in making good doctors? BMJ 2002; 325:707-10.

9. Salam A, Song CO, Mazlan NF, Lee LS, A bdullah MH, Hassin H. Professionalism of Future Medical Professionals in Universiti Kebangsaan Malaysia (UKM) Medical Centre. Int Med J 2012;19(3):224-8.

10. Passi V, Johnson S, Peile E, Wright S, Hafferty F, Johnson N. Doctor role modelling in medical education: BEME Guide No. 27. Med Teach 2013; 35: e1422-e1436.

11. Mileder LP, Schmidt A, Dimai HP. Clinicians should be aware of their responsibilities as role models: a case report on the impact of poor role modelling. Med Educ Online 2014; 19: 23479.

12. Wright SM, Carrese JA. Excellence in role modelling: insight and perspectives from the pros. CMAJ 2002;167(6):638-43. 